\title{
Study on Chinese Excellent Traditional Culture in Practical Teaching of Ideological and Political Theory Courses in Colleges and Universities
}

\author{
Taking Tea Culture as an Example*
}

\author{
Weifang Xue \\ School of Maxism \\ Anshun University \\ Anshun, China 561000
}

\begin{abstract}
Learning and mastering the various ideological essences of Chinese traditional culture is very beneficial to establishing the correct three contemplations. Tea culture is an important component of Chinese traditional culture. Its essence is mainly reflected in the tea spirit of "harmony, quietness, comfort, and truth". At present, the practical teaching of ideological and political theory courses in colleges and universities has the problems of loss of "true", less "quiz", lack of "quietness" and "harmony". It is not only a new attempt to integrate the tea culture into practical teaching of ideological and political theory courses in colleges and universities, but also a new perspective and new path for colleges and universities to constantly explore the practice and educating mechanism.
\end{abstract}

Keywords-tea culture; ideological and political theory courses; practical teaching

\section{INTRODUCTION}

The ideological and political theory course in colleges and universities is the main channel and main position for ideological and political education of college students, and shoulders the important task of helping undergraduates to establish a correct world outlook, outlook on life, and values. The practical teaching of ideological and political theory course in colleges and universities is necessary to promote the internalization of ideological and political theory of undergraduates and realize the unity of knowledge and practice. General Secretary $\mathrm{Xi}$ Jinping pointed out that traditional Chinese culture is extensive and profound, and learning and mastering the various ideological essences therein is beneficial to establishing a correct world outlook, outlook on life, and values. [1] Tea culture is an important part of Chinese traditional culture. Taking the tea culture as the perspective, this paper investigates the dilemma faced by the practical teaching of ideological and political theory courses in colleges and universities, and integrates tea culture into practical

*Fund project: The periodical achievements of "Research on the stratification practical teaching of ideological and political theory courses in colleges and universities" (Project number: 2015ZXJG007) in the provincial teaching quality engineering project of Anshun College specially supported by Education Department of Guizhou province. teaching of ideological and political theory, which is a new perspective and new path for universities to constantly explore the practice and educating mechanism.

\section{Tea CUlture Contains Rich EsSENCE OF Traditional Chinese CULTURE}

Tea is the national drink of the Chinese nation. $\mathrm{Lu} \mathrm{Yu}$, a famous tea expert in the Tang Dynasty known as "tea saint" recorded in The Classic of Tea Liuzhiyin that "tea is a kind of drink, it is originated from Shen-nong-shi, and it is heard by Lu Zhougong", it is enough to see that Chinese tea culture has a long history. Tea culture combines the ideological essence of traditional Chinese Confucianism, Taoism, and Buddhism, and has become a wonderful work in Chinese traditional culture. Tea culture is rich in connotation, including tea art, tea ceremony, tea virtues, tea customs, tea banquet, tea party and so on, but its essence is mainly reflected in the spirit of tea ceremony. They are concentrated as four principles of "harmony, quietness, comfort and truth", which are not only the philosophical approach pursued by traditional Chinese culture but the essence of traditional Chinese culture.

\section{A. Harmony - The Core Essence of Chinese Tea Ceremony Spirit}

Tea ceremony is not only the ceremony to prepare tea and taste tea, but also to realize and explore the connotation of the thought in the process of drinking tea, to cultivate the sentiment and enhance the connotation of the thoughts in the way of tasting tea. [2] The essential spirit of Chinese tea ceremony is to guide individuals to complete character cultivation in the enjoyment of beauty through the process of tea, in order to realize self and transcend the self. In terms of spiritual pursuits, the pursuit of "harmony" in tea ceremony means the harmony and unity of all things in the universe, and the resulting harmonious beauty of heaven and man, which is the perfect unity of heaven, earth, and human. In the book Classic of Tea, $\mathrm{Lu} \mathrm{Yu}$, the tea saint, describes the tea wares as five elements of gold, wood, water, fire and earth and the process of boiling tea is the process of the five elements working together to achieve balance and harmony. In the 
history of tea culture, Confucianism, Buddhism and Taoism have their own interpretations of the concept of "harmony" in tea ceremony, but the core content of the interpretations is "harmony", individual self-harmony, harmony between different individuals and harmony between individual and nature. Chinese tea lovers of all generations also take "harmony" as the soul of tea, constantly practice and realize in the process of researching tea, and realize and surpass themselves in the pursuit of the essence of "harmony".

\section{B. Quietness - The Necessary Way for Chinese Tea Ceremony}

Tea ceremony is the ceremony of self-cultivation and selfpursuit, but how to achieve the realm of the tea ceremony, "quietness" is the necessary way of cultivate and practice. Drinking tea is called taste tea, not drinking tea. The difference is that taste tea can achieve the spiritual sublimation of the self from the beauty of the physical form of tea. At the time of tasting tea, when the fragrance of tea is quietly filled and infiltrated with the hearts of tea taster, the mind of whose will be exceptionally clean under the influence of tea, and the spirit of tea taster will also be purified and sublimated guided by tea. The ancient saying goes that once achieve the word "quietness", you can see everything. Throughout the ages, no matter Buddhist monks, Taoists or Confucian scholars, they all regard "quietness" as the necessary way of self-cultivation. Only "quietness" can achieve highest good is like water, and very modest, which is exactly the realm described as "there is no magic except for "quietness" if you want to reach the mystery of the tea ceremony".

\section{Comfort - The Physical and Mental Feeling of Chinese Tea Taster}

"Comfort" expresses the physical and mental sentiments and experience that brings to the tea tasters. There are three levels of "comfort" of tea ceremony, that is, comfort of feeling, comfort of body and mind and comfort of spirit. Comfort of feeling means that in the activities of tea ceremony, the beauty of the intuitive enjoyment of tea by sensory organs. Whether it is a quiet tea environment, or a beautiful tea set, or intoxicating tea and sweet tea, it can make tea taster feel happy on the sensory organs. Comfort of body and mind means that in the activities of tea ceremony, the color, fragrance and taste of tea will deepen tea tasters' understanding of tea ceremony spirit and make tea taster feel relaxed and happy. Comfort of spirit means that in the activities of tea ceremony, through a variety of mental activities such as knowledge, affection, and intention, the product has developed a deep meaning of tea and realized the spirit of tea ceremony and reached the highest level.

\section{Truth - The Final Pursuit of Chinese Tea Ceremony}

"Truth" is the starting point and final pursuit of Chinese tea ceremony. Truth is the opposite side of false, "truth" in Chinese tea ceremony has four meanings: truth of things, love, nature and ceremony. Pursue the things truth means "truth" in the activities of tea ceremony. Tea must be real tea, real fragrance and real taste, tea ceremony environment is of real mountain, real water and real flower and tea ware must be real bamboo, real pottery, real stone and etc. to pursue the most real material; the pursuit of real love means that the tea taster achieves the realm of mutual understanding through mutual appreciation of taste tea; the pursuit of real nature means that the tea taster will really relax themselves in the process of tasting tea, and achieve a pure and natural state in the realm of selfness; the pursuit of real ceremony means that the tea taster finally reach the highest level of self-cultivation, cultivation of sentiment, cleansing of the soul and enjoyment of life through tea activities.

\section{THE DILEMMA OF THE PRACTICAL TEACHING OF IDEOLOGICAL AND POLITICAL THEORY COURSES IN CHINESE UNIVERSITIES FROM THE PERSPECTIVE OF TEA CULTURE}

Practical teaching is an important means to mobilize the enthusiasm of undergraduates and improve the overall quality of undergraduates. It is an important way to enhance the effectiveness of ideological and political education in colleges and universities and to link theory with practice. It is an objective need and an inevitable choice for adapting to the cultivation of talents and promoting social development. [3] Strengthening practical teaching is an important measure for carrying out and educating the people and actually improving the effectiveness and pertinence of ideological and political education. However, due to the influence of the nature of the course and the subject and object of teaching, there are still some problems in the practical teaching of the current ideological and political theory courses, which makes practical teaching less effective and pertinent, and the goal of practical teaching is difficult to achieve. From the perspective of tea culture, the current problems in the practical teaching of ideological and political theory courses in universities are as follows:

\section{A. The Teaching Method Is Outdated, and the Practice Form Loses Its "Truth"}

Practical teaching of ideological and political theory courses in colleges and universities usually has two forms of practice within colleges and universities and practice outside colleges and universities. The practice in the colleges and universities mainly focuses on writing after reading of undergraduates, watching videos, writing ideas, case discussions, undergraduate debate games, situational simulation teaching and some other forms in and after classes; off-campus practice is usually based on visits and inspections, participation in off-campus charitable activities, or rural areas or summer social practice surveys. It is known through the task group's investigation into the development of practical teaching of ideological and political theory courses in some colleges and universities that at present, some colleges and universities are constrained by factors such as inadequate funding for ideological and political theory and imperfect construction of practical teaching bases, and in practical teaching, teaching methods are too old, lack of creativity, and the practice forms are simple, and unproblematic; in addition, some teachers have deviated from the real purpose of practical teaching in order to please students and adopt simple fancy forms in practice. For example, the phenomenon "teacher wear imperial robe to give classes of Essentials of Chinese Modern History on the internet, in order to attract the students' 
attention, teachers try their best to create teaching methods and how effective it is and how long the students' attention will last is debatable. Such kind of phenomenon of losing "truth" practice teaching form causes the practical teaching of ideological and political theory courses either because of lack of lively and attractive forms and no new ideas or appearance in a seemingly rich and varied form of practice, there are a large number of problems that exist in isolation from the teaching goals.

\section{B. Duplicate Content Lacks Innovation, and Practical Experience Is of Less "Comfort"}

The teaching of ideological and political theory courses in colleges and universities is to carry out ideological and political education for undergraduates. To be effective in teaching, it is necessary to enhance teaching pertinence in practical teaching. If there is no specific teaching, undergraduate will not feel the relationship between the teaching and the issues he is concerned with. If he does not feel the relationship with the questions he is perplexed by, he would not approach the teaching actively, nor would he be fully engaged in teaching, nor would he be close to or confirm teaching. [4] At present, the ideological and political theory courses in colleges and universities carry out practical teaching based on the actual situation of undergraduates and the current social hot spots. Since the four ideological and political theory courses often belong to different teaching and research sections, most colleges and universities lack the overall consideration and overall planning of the practical teaching of ideological and political theory courses. In the design of practical teaching programs, it is often overlooked that layered teaching is based on the content of the course and the students' majors. This results in students having repetition in practice content without experiencing the joy of practice. For example, some classes have already conducted a patriotism practice base visit education in the course of Ideological and Moral Cultivation and Legal Basis. However, in the practice of the Essentials of Chinese Modern History, there are still different practical contents for different teachers. As a result, students turn up their previous assignments to cope with, and students do not experience happiness and attainment at all in similar practices.

\section{Students' Utilitarian Thinking Is Serious, and the Practice Subject Lacks "Quietness",}

Tea usually grows beautiful place, which gathers the excellent spirit of mountain and rivers, the glory of sun and moon. But if the tea taster wants to enjoy the taste of the tea ceremony, he must calm down before he can enjoy it. Due to the influence of market economy, compared with professional courses, the ideological and political theory courses that are the nature of public courses are just some of the courses that students have to deal with in order to graduate or pass the examination. This kind of practical teaching with utilitarian attitudes makes most students engaged in it with impetuous psychology. The main performance is that during the practice process, it is not at all easy to conduct data review and design, and it is not possible to concentrate on meticulous investigations. The practical results are mostly copied or plagiarized by the network. Such practice cannot achieve the effectiveness and purpose of practical teaching.

\section{Comprehensively Affected by Subjective and Objective Factors, the Practice Effect Is of No "Harmony"}

Theoretically, practice teaching is an important measure to enhance the effectiveness of ideological and political teaching in colleges and universities and to link theory with practice and it is an important channel for mobilizing the enthusiasm of undergraduates and improving their overall quality. But in the actual practical teaching, due to the restriction of the funds and practice place, he limited practical thinking of the instructors, etc., the practice teaching of ideological and political theory courses in most colleges and universities has problems such as outdated practice methods, monotonous practice forms, and duplication of practice contents. In addition, the practice subject has a certain prejudice understanding of the ideological and political theory course, which makes the practical influence less effective, and fails to reach the practical teaching goal of "internalizing the mind and externalizing it".

\section{THE TEA CUlture Is INTEGRATED INTO THE PATH} EXPLORATION OF THE PRACTICAL TEACHING OF IDEOLOGICAL AND POLITICAL THEORY COURSES IN CHINESE UNIVERSITIES

$\mathrm{Xi}$ Jinping points out in the speech at the National Conference on Ideological and Political Work in Colleges and Universities that in order to do well in ideological and political work in colleges and universities, it is necessary to make good use of classroom teaching as the main channel and main position. Ideological and political theory courses must be strengthened in the improvement and promoted in development so as to constantly satisfy students' growth needs and expectations. [5] Form the perspective of tea culture, it is necessary to explore and improve ideological and political practice teaching in colleges and universities from the following aspects.

\section{A. To Introduce Tea Culture into Theoretical Teaching and Expand the Content of Practice}

When discussing traditional Chinese culture, Xi Jinping points out that it is necessary to clearly explain the historical origins, development context, and basic trends of Chinese excellent culture, and to clearly explain the unique value, distinct characteristics, and enhance cultural confidence and value confidence of Chinese culture. [1] As an important component of Chinese excellent traditional culture, tea culture should be the teaching content of ideological and political courses in colleges and universities. Combining the teaching contents of relevant course chapters, it clarifies the history, profound meaning and value concept of tea culture to contemporary undergraduates, and further explores and interprets the value of tea culture in the era so that students can fully understand the cultural values and moral norms covered in the concept of tea ceremony and enhance cultural confidence and value confidence. For example, when teaching "One Belt and One Road", teachers can let students understand the history of tea culture in China through watching videos of ancient tea-horse road; when teaching socialist core values, intersperse with the essence of tea culture, and promote effect 
of undergraduates' ideological and political education through the organic integration of tea ethics, tea ceremony spirit and modern moral education.

\section{B. To Stratify Students by Combining Tea Culture and Innovate the Forms of Practice}

In order to be attractive, the forms of practice must be innovated in practical teaching. From the perspective of tea culture, the practical teaching of ideological and political theory courses can be carried out. Students can be stratified according to students' specialties and characteristics, and class practical activities can be carried out on the theme of tea culture. For example, appreciation of tea poems can be used to major of Chinese language and literature or ancient Chinese, pictures, dance and songs of tea can be shown to major of arts, tea etiquette learning and performance should be conducted in major of secretarial, tea stories can be developed to be familiar with history for major of history, discussion on tea customs for the major of ethnology and so on to innovate the forms of practice. The experience of tea activities combined with students' majors and interests can improve their enthusiasm and creativity, and enhance the effectiveness and appeal of practical teaching.

\section{To Combine the Policy of "Come in" and "Go out", Enhance the Experience of Practice}

If you want to make practice subjects enhance practice understanding, you should create certain practical situations and develop situational teaching. Based on the tea culture perspective, we can use the combination of policy "come in" and "go out". "Come in" refers to the establishment of a tea culture association or tea culture community, and regularly invite tea garden expert and gardeners to give lectures, communication and interaction to students so that they can understand the connotation of Chinese tea culture and feel the cultivation and moral education in tea culture. "Go out" refers to the development of tea culture practice education bases, lead students to visit tea gardens on the ground, help tea farmers to pick tea-leaves, observe tea performances, and conduct tea ceremony experiences, which enables tea culture to purify and improve the soul of students in the silence and promote to achieve the purpose of practical teaching of ideological and political theory courses.

\section{CONCLUSION}

Chinese culture has a long history, and tea culture, as an important component of Chinese excellent traditional culture, contains rich philosophical ideas and moral concepts. Inheriting and carrying forward the essence of Chinese traditional culture is an important task in the teaching of ideological and political theory in colleges and universities. Integrating tea culture into practice teaching of ideological and political theory courses in colleges and universities is not only a new attempt, but also a new perspective and a new way to promote colleges and universities to explore practice education. It is the active exploration of strengthening and improving the infectivity and pertinence of ideological and political education in the advancement of ideological and political theory courses.

\section{REFERENCES}

[1] Editorial department of this magazine. Discuss on Chinese traditional culture of Xi Jinping--- Selection of important expositions since the 18th National Congress [J]. Party construction, 2014 (3): 7-9. 本刊编辑 部. 习近平论中国传统文化一一十八大来重要论述选编 $[\mathrm{J}]$. 党 建,2014（3）:7-9.

[2] Wang Shunzhi. Tea ceremony [M]. Changchun: Jilin Publishing Group Co., Ltd., 2016. 王舜之. 茶道[M]. 长春: 吉林出版集团股份有限公 司,2016.

[3] Jiang Guofeng, Li Min. Construction of "layer integration" mode in the practice teaching of ideological and political theory courses in colleges and universities [J]. Journal of Baoshan University, 2014 (6): 79-85. 姜 国峰, 李敏.高校思想政治理论课实践教学 “分层一体化” 模式构 建 $[J]$.保山学院学报,2014（6）:79-85.

[4] Bai Xianliang. On the logic generation of teaching affinity of ideological and political theory courses in colleges and universities [J]. Ideological and Theoretical Education Guide, 2017 (4): 17-22. 白显良. 论高校思想政治理论课教学亲和力的逻辑生成 [J].思想理论教育导 刊，2017（4）:17-22.

[5] Xi Jinping emphasized at the national conference on ideological and political work at colleges and universities: To create a new situation for the development of higher education in China through ideological and political work throughout the entire process of education and teaching 习近平在全国高校思想政治工作会议上强调：把思想政治工作贯穿 教育教学全过程开创我国高等教育事业发展新局面[N].人民日报, 2016-12-09 (1). 